\title{
Review of Handbook on contemporary Austrian economics, edited by Peter J. Boettke. Cheltenham (UK): Edward Elgar, 2010, 174pp.
}

\author{
DAVID HOWDEN \\ St. Louis University, Madrid Campus
}

Peter J. Boettke brings together ten third-generation "modern" Austrian economists to outline ten core propositions of the Austrian school of economics. ${ }^{1}$ The edited collection is a further development of Boettke's 2008 entry to the Concise encyclopedia of economics entitled "Austrian school of economics". While the core tenets of Austrian economics are certainly open to debate, Boettke meets the challenge and the propositions provide the reader with his particular view of the discipline.

The Austrian school of economics exists largely as a heterodox school outside of the mainstream of economic thought. It has its share of controversies, both internally and with its more orthodox peers. The most visible defining characteristic of the school-and what is likely the aspect most interesting to the majority of EJPE readers-is its methodological base. Shunning positivist and empiricist approaches, the Austrian school generally applies deductive reasoning (mostly of the verbal form) to construct theory. From this basis spring further distinctions of varying degrees between Austrian economists and the mainstream, which provide the primary fodder for this book.

The book is structured similarly to other recent overviews of Austrian economics, and complement texts such as Boettke (1994) and Huerta de Soto (2010). It sets itself apart by being a little more systematic, focused and, in the end, geared at a different audience. It is systematic in the sense that the reader does not need to work too hard to understand exactly what the authors are trying to stress-the

\footnotetext{
${ }^{1}$ A complete listing of the ten propositions is as follows: 1) only individuals chose, 2) the study of the market order is about exchange behavior, 3) the "facts" of the social sciences are what people believe, 4) utility and costs are subjective, 5) prices economize on information people need for decision making, 6) private property in the means of production is a necessary condition for rational economic calculation, 7) the competitive market is a process of entrepreneurial discovery, 8) money is non-neutral, 9) the capital structure consists of multispecific and heterogeneous goods, and 10) social institutions are the result of human action, but not of human design.
} 
ten propositions clearly form the basis of the body of knowledge being imparted. The use of ten propositions reminds this reviewer of N. Gregory Mankiw's “10 principles of economics” that open the pages of his widely read introductory textbook to neoclassical economics. The uninitiated to Austrian economics will be at ease in these pages, as the overview sticks to the basic points. The contributing authors also provide enough depth to hold the attention of intermediate-level Austrian economists.

While methodological differences differentiate the Austrian from the mainstream economist, there is also considerable debate within the school. What is the proper use of empirical facts? Should theory be constrained to strictly a priori statements, or are even these tainted by empirical influences? For the most part this book wisely sidesteps such issues, and instead focuses on the central features of the methodological divide with mainstream economics.

Without getting embroiled in specific debates as to what defines the Austrian school, Boettke aims to delineate what sets it apart from its more mainstream peers. Most of the ten entries are noncontroversial and unique to the Austrian school (or at the least, are outside of the mainstream of economic reasoning). In particular this reviewer is thinking of proposition 4: utility and costs are subjective, and proposition 8: money is non-neutral. Other propositions, however, could find themselves at home in the mainstream economist's toolbox. Proposition 1: only individuals choose, as a case in point, is unobjectionable to many microeconomists (perhaps behaviorists aside), regardless of their preferred school. Likewise, proposition 5: the price system economizes on information people need to make decisions, is well incorporated in the corpus of mainstream economic theory (indeed, it could be the contribution of Friedrich Hayek best incorporated by the mainstream, though there is more to say on that later).

In what follows, I wish to overview some of the more stimulating contributions, before turning to the real strengths (and weakness) of the book.

Anthony J. Evans takes the contemporary understanding of the term "methodological individualism" to task as a vulgar version of its original use. Modern usage has the economist reducing all complex phenomena to their most elemental (individual) components for further analysis. Evans advocates instead an "institutional individualism" approach, whereby one can still reduce actions to an atomistic level yet remain 
cognizant of more institutional (and less individual) influences. While reading in many ways like a redefinition of existing terminology, the chapter is more of a rallying call to return to the original use of methodological individualism. While reducing social phenomenon to their primal elements clarifies many ambiguities, there is no denying that the "group" influences many actions. Evans's middle ground approach allows for just the right amount of attention to the individual while paying heed to institutional influences.

In two complementary chapters, Virgil Henry Storr and Edward P. Stringham discuss the problem of subjectivity in economic science. Storr takes a more theoretical approach, explaining why any interpretation of events must be subjective. He ably sidesteps controversies over how "subjective" different analyses are, while succinctly making the case for a subjective core for economics. Stringham addresses the question of how "subjective" one is by compiling a "Subjectivism purity test" for the reader to establish to what degree they believe the facts of social sciences are subjective. Interesting results abound.

One of interest to this reviewer is Stringham's conclusion that "[f]rom this perspective the famous mathematical economist Kenneth Arrow was more of an economic subjectivist than Mises!" (p. 54). Stringham refers to Mises's explicit preference for a certain state of the world, versus Arrow's acceptance that an optimal state is indefinable. This reviewer thinks that Stringham overstates his case. One can prefer, after all, a certain outcome (and advocate for it) and still remain subjectivist provided one does not attempt to impose this state onto others.

Stephen C. Miller contrasts two views of prices and their role in the market. The neoclassical economist views a price as a summary of an existing equilibrium situation. The Austrian views a price as an active protagonist in the entrepreneurial discovery process, spreading information effortlessly to various agents. Indeed the difference is subtle, and Miller serves the reader well to shed light on the different approaches. While the neoclassical focus emphasizes the process that prices undergo to get to a new equilibrium, the Austrian counterpart emphasizes the process by which demanders of a good respond to price changes. While the mainstream has superficially incorporated Hayek's stress on the role of prices in the market economy, Miller guides the reader through the intricate role that prices actually play. 
Frederic Sautet outlines the intimate relationship between competition and entrepreneurship. In one interesting schema, Sautet lists and differentiates between three definitions of a "market": the old classical view of a market as a place; the Austrian view of a market as a process; and the now more mainstream conceptualization of a market as a metaphor. This reviewer was struck by how useful this trichotomy was in identifying where some aspects of economic theory have gotten off-track. The shift of the most generic institution of economic theory-the "market"-from a place (a spatial relation) to a process (a temporal relation) to a metaphor (an abstract relation) has resulted in a purging of some essential facets from economic theory. As Sautet outlines, chief among these facets are the entrepreneurial function and its competitive nature.

In many respects Austrian economists differ from their more mainstream peers the most in the area of monetary economics. J. Robert Subrick sheds light on the reasons for non-neutral money and its implications. Bringing attention to the six main rationales for money's non-neutrality, Subrick clearly shows where Austrian economists have established themselves, and where more work needs to be done. In comparison to their mainstream colleagues, Austrians have paid plenty of attention to the negative consequences of Cantillon effects and forced saving; certain strands of Austrian economics have focused on the money illusion and sticky prices; while Mundell-Tobin effects remain relatively underexplored. Subrick could have paid closer attention to the distinction between commodity and fiat money, and its implications for price stickiness, but on the whole the chapter gives the reader a refreshing primer on the current state of understanding of the concept of non-neutral money among Austrian economists.

In the book's final chapter, Boettke closes by providing a glimpse of what will feature in Austrian economics in the future. This chapter forms, in many ways, an eleventh proposition to augment the previous ten. By outlining two central methodological tenets of Austrian theorizing-praxeology and apriorism-Boettke overviews the epistemological issues that the Austrians of yesteryear have defended against, in order to direct the reader to a possible future. Methodological concerns are certainly central to most Austrian-type analyses, but this reviewer has mixed feelings about their isolation to the final pages of the book. On the one hand, these concerns receive so much attention elsewhere that it is not completely necessary to 
rehash them afresh. Then again, since they are undeniably distinct and defining features of this school of economics, a more thorough inclusion is almost certainly warranted. At the end of the day, this is one topic that will likely please some readers while irking others.

Perhaps the largest misgiving I have of the book is the attempt to pigeonhole these ten Austrian propositions into categories more at home in its mainstream counterparts. By splitting the propositions into three separate parts of the book-the science of economics, microeconomics, and macroeconomics-Boettke is forced to almost redefine concepts to accommodate non-relevant categories. As an example, proposition 10 (concerned with spontaneously formed social orders) does not seem at home in a macroeconomics oriented section. At the same time, it does not seem overly at home in any of the other sections. It could be that Boettke's ten propositions do not easily fit into the more mainstream micro/macro divide. Trying to fit them into that mold makes the flow of the book a little clumsy, but does not meaningfully affect the knowledge being imparted.

In sum, the book is a concise overview of some of the distinctive features of Austrian economics. One could debate whether other facets should have been included (the aforementioned methodological concerns spring to mind). Likewise some will take issue that some topics are not sufficiently "Austrian", or uniquely so, to warrant inclusion. Whatever one's take on that, forming a central core of propositions that a group can identify with is a necessary condition for that group moving forward as a cohesive whole. In that regard, Boettke has moved his group in the right direction.

\section{REFERENCES}

Boettke, Peter J. (ed.). 1994. The Elgar companion to Austrian economics. Aldershot (UK): Edward Elgar.

Boettke, Peter J. 2008. Austrian school of economics. In Concise Encyclopedia of Economics, ed. David R. Henderson. Library of Economics and Liberty. Liberty Fund, Inc. http://www.econlib.org/library/Enc/AustrianSchoolofEconomics.html (accessed May 26, 2012).

Huerta de Soto, Jesús. 2010. The Austrian school: market order and entrepreneurial creativity. Cheltenham (UK): Edward Elgar.

David Howden is assistant professor of economics at St. Louis University at its campus in Madrid, Spain. His research interests include the Austrian theory of the business cycle and its implications for 
banking policy. His most recent book is Institutions in crisis: European perspectives on the recession (editor, 2011, Edward Elgar).

Contact e-mail: <dhowden@slu.edu> 